\title{
Variasi Genetik Lokus Mikrosatelit D7S1789 pada Populasi Monyet Ekor Panjang di Gunung Pusuk Lombok Barat
}

\author{
(GENETIC VARIATION OF D7S1789 MICROSATELLITE LOCUS IN LONG-TAILED \\ MACAQUES AT MOUNT PUSUK WEST LOMBOK)
}

Febio Tomasini Marciano Meus ${ }^{1}$, I Nengah Wandia ${ }^{2,3, *}$, I Ketut Suatha ${ }^{2,3}$

\author{
${ }^{1}$ Praktisi Dokter Hewan di Kabupaten Manggarai Timur, Nusa Tenggara Timur, Indonesia \\ 86571 ; \\ ${ }^{2}$ Laboratorium Anatomi Veteriner, Fakultas Kedokteran Hewan, Universitas Udayana Jl. PB. \\ Sudirman, Denpasar, Bali Indonesia 80234; \\ ${ }^{3}$ Pusat Penelitian Satwa Primata LPPM Universitas Udayana, Jl. Raya Kampus Udayana, \\ Bukit Jimbaran, Kuta Selatan, Badung, Bali, Indonesia 80361. \\ *Email: wandia@unud.ac.id
}

\begin{abstract}
ABSTRAK
Monyet ekor panjang (Macaca fascicularis) merupakan hewan endemik Asia Tenggara dengan pola hidup dan interaksi yang membentuk kelompok kohesif yang protektif dengan teritori wilayahnya. Pola demikian menciptakan kekhasan karakter antar populasi seperti variasi lokus mikrosatelit. Penelitian ini mengungkapkan polimorfisme lokus mikrosatelit D7S1789 pada populasi monyet ekor panjang di Gunung Pusuk Lombok Barat dengan tujuan mengetahui jumlah alel, frekuensi alel, heterozigositas dan keseimbangan Hardy-Weinberg berdasarkan sebaran alelnya menggunakan uji Chi-square. Sejumah 17 sampel darah monyet ekor panjang dari populasi Gunung Pusuk Lombok Barat diekstraksi untuk mendapatkan DNA total. Ekstraksi DNA menggunakan QIAmp DNA blood kits dari QIAGEN. Lokus mikrosatelit D7S1789 diperbanyak menggunakan teknik PCR sebanyak 30 siklus, dengan suhu annealing $57^{\circ} \mathrm{C}$. Alel dimunculkan dengan pewarnaan perak menggunakan gel poliakrilamid $8 \%$. Hasil didapatkan dua alel dengan frekuensi masing-masing 121 bp $(0,794)$ dan 130 bp $(0,206)$, serta heterozigositas $(0,337)$. Uji keseimbangan Hardy-Weinberg $\left(\chi^{2}\right.$ hitung $)$ adalah $0,422\left(\chi_{\text {tabel }}^{2}=3,841 ; \alpha=\right.$ 0,$05 ; \mathrm{db}=1$ ) yang mengindikasikan populasi kawin acak. Dari hasil penelitian dapat disimpulkan bahwa lokus mikrosatelit D7S1789 bersifat polimorfik pada populasi monyet ekor panjang di Gunung Pusuk Lombok Barat.
\end{abstract}

Kata kunci: Monyet ekor panjang; variasi genetik; mikrosatelit D7S1789; Gunung Pusuk

\begin{abstract}
Long-tailed macaques (Macaca fascicularis) are Southeast Asian endemic animal with its behaviors and interactions form a protective cohesive group on its territory. Such patterns create distinctions that can be detected by microsatellite variations. This study revealed polymorphism of the D7S1789 microsatellite locus in a population of long-tailed macaques in Mount Pusuk West Lombok with the aim of knowing the genetic variation in the form of number of alleles, allele frequencies, heterozygosity and Hardy-Weinberg Equilibrium based on its allele's distributing the Chi-square test. A total of 17 blood samples of long tailed macaque extracted used QIAamp DNA blood kit from QIAGEN to get DNA, DNA from locus D7S1789 microsatellite was replicated through 30 cycles of PCR technique, with annealing temperature $57^{\circ} \mathrm{C}$. The alleles were raised by silver staining using $8 \%$ polyacrylamide gel. The results obtained two alleles with a frequency of $121 \mathrm{bp}(0.794)$ and $130 \mathrm{bp}(0.206)$, heterozygosity ( 0.337$)$ and Hardy-Weinberg Equilibrium test ( $\chi^{2}$ count) was $0.422\left(\chi^{2}\right.$ table $=3.841 ; \alpha$ $=0.05 ; \mathrm{db}=1)$ which indicates a random mating population. It can be concluded that the D7S1789 microsatellite locus was polymorphic in the population of long-tailed monkeys in Mount Pusuk, West Lombok.
\end{abstract}

Keywords: Long-tailed macaques; genetic variation; D7S1789 microsatellite; Mount Pusuk. 


\section{PENDAHULUAN}

Monyet ekor panjang (Macaca fascicularis) merupakan hewan endemik yang dapat ditemukan di beberapa daerah di Asia Tenggara, diantaranya Filipina, Malaysia, Burma, India, Kamboja, Laos, Thailand dan Indonesia (Lang dan Crockett, 2006; Fooden, 2006). Pola hidup dan interaksi sosial Macaca fascicularis membentuk kelompok kohesif dan protektif terhadap teritori wilayahnya (De Ruiter dan Geffen, 1998; Karimullah dan Anuar, 2011) menyebabkan suatu populasi terpisah dengan populasi lainnya, walaupun jantan dapat bermigrasi dari satu populasi ke populasi lainnya (De Ruiter dan Geffen, 1998). Selain itu, kondisi geografis yang terjal dan diselingi dengan pemukiman penduduk menyebabkan migrasi jantan antar populasi menjadi sulit (Eudey, 1994). Salah satu contoh adalah populasi monyet ekor panjang di Gunung Pusuk, Pulau Lombok.

Gunung Pusuk termasuk dalam deretan pegunungan menengah di sekitar puncak Rinjani. Dengan ketinggian $831 \mathrm{~m}$ diatas permukaan laut, Gunung Pusuk memiliki hutan yang menghubungkan antara kabupaten Lombok Barat dan Lombok Utara. Perlintasan jalan umum yang ada sepanjang gunung ini dibuat untuk menghubungkan kedua kabupaten tersebut. Akses jalan yang ada kemudian memisahkan populasi yang satu dengan yang lainnya. Tiadanya migrasi antar populasi ini dapat meningkatkan status isolasi sehingga meningkatkan peluang inbreeding serta menurunkan diversitas atau variasi genetik populasi (Dewi et al., 2013; Dwiwandana et al., 2013).

Variasi genetik populasi dapat diungkapkan dengan berbagai metode, salah satu metode yakni DNA mikrosatelit (Balloux dan Lugon-Moulin 2002; Monica et al., 2012; Dewi et al., 2013; Maharani et al., 2014) telah banyak dilakukan karena beberapa keunggulan yang ditawarkan, diantaranya: mudah diamplifikasi dengan PCR dan panjang pengulangannya yang pendek (Gemayel et al., 2010). Mutasi suatu lokus mikrosatelit melalui penambahan atau pengurangan motif menyebabkan alel mikrosatelit mudah dibedakan dengan elektroforesis konvensional (Wandia, 2001).

Lokus mikrosatelit D7S1789 merupakan suatu lokus dengan motif $3 \mathrm{bp}$ (TAC) (Alders et al., 2017) dan berasal dari kromosom ketujuh monyet ekor panjang (Wienberg dan Stanyon, 1998). Penelitian yang menggunakan lokus mikrosatelit D7S1789 telah dilaporkan sebelumnya di Wanara Wana (Dwiwandana et al., 2013) dengan jumlah alel satu, yakni 216 bp dan bersifat monomorfik.

Tujuan penelitian ini adalah untuk mengetahui jumlah alel, frekuensi, nilai heterozigositas, serta sebaran alel dari lokus D7S1789 pada populasi monyet ekor panjang di Gunung Pusuk Lombok Barat.

\section{METODE PENELITIAN}

\section{Koleksi darah sampel}

Sampling monyet ekor panjang dilakukan secara acak. Sebanyak 17 ekor monyet ekor panjang dibius dengan jalan ditulup menggunakan anestesi kombinasi ketamin $\mathrm{HCl}$ dosis $10 \mathrm{mg} / \mathrm{kgBB}$ dan Xilazine dosis 2-3 mg/kgBB (Suartha et al., 2002). Darah dikoleksi sebanyak 5-10 ml melalui vena femoralis menggunakan alat suntuk $10 \mathrm{ml}$, kemudian ditambahkan 0,10,4 ml EDTA 10\% sebagai antikoagulan.

\section{Prosedur penelitian}

Ekstraksi DNA menggunakan QIAmp DNA Blood kit. Lokus mikrosatelit diamplifikasi menggunakan mesin Real Time PCR (Rotor Gene-Q seri 0514122 type RQ-Plex) dengan menggunakan sepasang primer, yakni forward 5, GAAAACAGTGATAGGAACCTGC 3' (22 basa) dan reverse 5' ATTCACCCTGCTCTCTAGGG $3^{\prime}$ (20 basa) yang berfungsi mengapit lokus mikrosatelit. Tiap unit reaksi PCR mengandung 1,25 buffer PCR 10x; $1 \mu 1$ $\mathrm{MgCl} 2$; dNTP 0,2 $\mu \mathrm{l}$; primer depan sebanyak $0,2 \mu \mathrm{l}$ dan primer belakang sebanyak $0,2 \mu \mathrm{l}$; air deionase sebanyak 8,45 $\mu \mathrm{l}$; template DNA sebanyak $1 \mu \mathrm{l}$ dan Taq DNA polymerase sebanyak $0,2 \mu$ l sehingga volume akhir 12,5 
$\mu 1$. Campuran divorteks dan disentrifugasi (Hillis et al., 1996). Kondisi PCR sebagai berikut: pra PCR satu siklus $\left(94^{\circ} \mathrm{C}\right) 3$ menit. PCR dilakukan sebanyak 30 siklus dengan tahapan sebagai berikut: tahapan denaturasi $\left(94^{\circ} \mathrm{C}\right)$ selama 35 detik, annealing $\left(57^{\circ} \mathrm{C}\right)$ selama 35 detik, dan elongasi $\left(72^{\circ} \mathrm{C}\right)$ selama 35 detik. Sedangkan post PCR: elongasi $\left(72^{\circ} \mathrm{C}\right) \quad 5$ menit. Hasil amplifikasi dipisahkan dengan elektroforesis menggunakan gel poliakrilamid 8\%, dijalankan pada tegangan 170 Volt selama 90 menit. Pita selanjutnya ditampilkan menggunakan pewarnaan perak dan pita diukur berdasarkan marker $100 \mathrm{bp}$.

\section{Analisis data}

Jumlah alel

Jumlah alel lokus mikrosatelit D7S1789 dihitung berdasarkan pita yang muncul pada gel poliakrilamid $8 \%$.

\section{Frekuensi alel}

Frekuensi alel dihitung menggunakan rumus Nei (1987)

$x i=\frac{2 N i i+\sum N i j}{2 N}$

Keterangan:

xi $=$ jumlah Frekuensi Alel i

Nii $=$ jumlah individu bergenotipe homozigot dengan Alel i

$\mathrm{Nij}=$ jumlah individu bergenotipe heterozigot dengan Alel i

$\mathrm{N} \quad=$ jumlah sampel

\section{Heterozigositas}

Nilai heterozigositas adalah ukuran keragaman genetik dalam suatu spesies dan dihitung dengan rumus tidak bias Nei (1987).

$h=\frac{2 n\left(1-\sum x i^{2}\right)}{(2 n-1)}$

Keterangan:

$\mathrm{h}=$ heterozigositas; $\mathrm{xi}=$ frekuensi alel $\mathrm{I} ; \mathrm{n}=$ jumlah sampel.

\section{Kawin acak}

Kawin acak ditampilkan oleh proporsi sebaran alel yang sesuai dengan keseimbanan

Hardy-Weinberg.

Keseimbangan HW diuji dengan Chisquare dengan formula sebauai berikut (Allendorf et al., 2013). Pengujian dilakukan dengan titik kritis $\alpha=0,05$.

$\chi^{2}=\sum \frac{(O i-E i)^{2}}{E i}$

Keterangan:

$\chi^{2}=$ Chi-square

$O i=$ Proporsi genotipe terobservasi ke-i

$E i=$ Proporsi genotipe harapan ke-i

Dengan derajat bebas $(\mathrm{db})$

$d b=T K G-J A T$

Keterangan:

TKG $=$ Total Kemungkinan Genotipe

JAT = Jumlah Alel Terobservasi

\section{HASIL DAN PEMBAHASAN}

Alel lokus mikrosatelit D7S1789 diukur dengan jarak migrasi pita pada gel poliakrilamid $8 \%$ setelah dielektroforesis selama 90 menit. Dengan adanya perbedaan migrasi pita alel tersebut maka nilai alel tersebut dapat ditentukan setelah dibandingkan dengan marker yang sudah memliki panjang tertentu (Krawscjack dan Schmidtke, 1994). Selanjutnya alel lokus dihitung dan lokus tersebut dinyatakan polimorfik jika jumlah alel pada lokus tersebut lebih dari satu dan frekuensi alel paling umum kurang dari atau sama dengan 0,95. Lokus mikrosatelit D7S1789 yang diuji pada populasi monyet ekor panjang Gunung Pusuk Lombok Barat mendapatkan dua alel yakni alel 121 bp dan 130 bp, serta bersifat polimorfik (Tabel 1).

Alel 121 bp merupakan alel dengan frekuensi tertinggi $(0,794)$ diikuti alel 130 bp dengan frekuensi $(0,206)$. Laju mutasi yang tinggi dalam populasi dapat saja mengakibatkan terjadinya kesalahan penerjemahan berupa penambahan dan pengurangan motif. Hal ini menjelaskan bagaimana jarak antara alel 121 bp dan 130 bp yang terpaut $9 \mathrm{bp}$. 


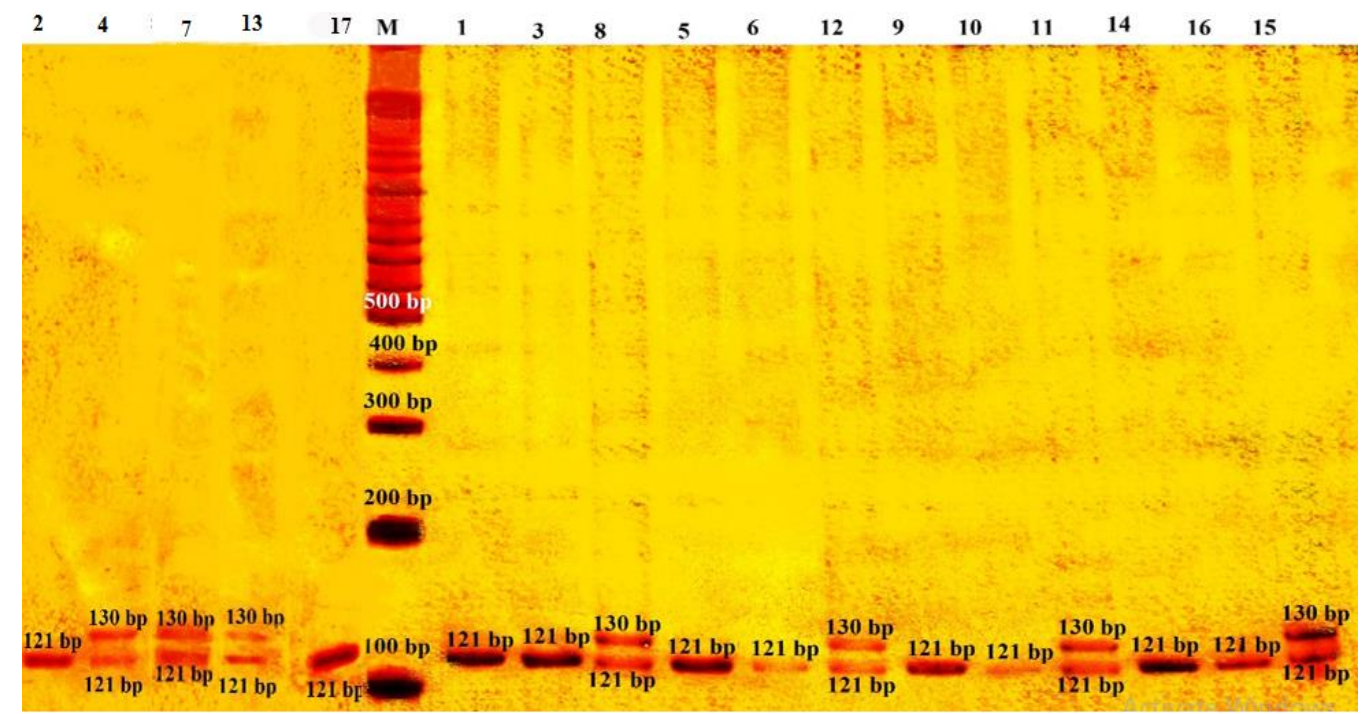

Gambar 1. Alel lokus mikrosatelit D7S1789 pada populasi Gunung Pusuk Lombok Barat. Nomor menyatakan sampel (individu), huruf M menyatakan marker 100 bp ladder. 121/121= $1,2,3,5,6,9,10,14,16,17 ; 121 / 130=4,7,8,11,12,13,15$.

Tabel 1. Frekuensi alel lokus mikrosatelit D7S1789 pada populasi monyet ekor panjang di Gunung Pusuk, Lombok Barat.

\begin{tabular}{llll}
\hline No & Alel & Jumlah & Frekuensi \\
\hline 1 & 121 & 27 & 0,794 \\
2 & 130 & 7 & 0,206 \\
\hline Total & 2 & 34 & 1 \\
\hline
\end{tabular}

Menurut Arisuryanti dan Daryono (2007), hal yang paling penting dalam menentukan kekhasan suatu populasi adalah dengan mengetahui frekuensi alel populasi, sebab dengan mengetahui frekuensi alel, karakterisasi populasi juga dapat dikenali. Frekuensi yang rendah dari alel 130 bp $(0,206)$ perlu mendapat perhatian. Rendahnya frekuensi alel $130 \mathrm{bp}$ dapat disebabkan karena adanya hanyutan genetik (random genetik drift). Namun berdasarkan porsi alel, diketahui alel tersebut bukan merupakan produk mutasi terkini karena mengisi hampir $21 \%$ porsi alel populasi Gunung Pusuk. Terlepas dari hal tersebut, alel lokus mikrosatelit D7S1789 yang didapatkan dari hasil penelitian ini merupakan suatu kekayaan genetik yang harus diselamatkan dari kepunahan. Oleh karenanya, tindakan konservasi yang tepat perlu diperhatikan agar kelangsungannya dapat terjaga.

Nilai heterozigositas yang didapatkan pada populasi monyet ekor panjang di
Gunung Pusuk Lombok barat adalah 0,337. Nilai ini cukup rendah yang mengindikasikan rendahnya keragaman genetik pada populasi ini. Namun hal ini masih lebih tinggi jika dibandingkan dengan populasi Monyet ekor panjang di Wanara Wana, Padang Tegal Ubud yang mendapatkan nilai $\mathrm{h}=0$ (Dwiwandana et al., 2013). Rendahnya nilai heterozigositas dapat dilihat dari rentangan nilai heterozigositas. Rentangan ini berkisar dari nol sampai satu. Semakin rendah nilai heterozigositas suatu populasi maka semakin membahayakan kelestarian suatu populasi karena munculnya alel yang homozigot (Allendorf et al., 2013).

Tabel 2. Keseimbangan Hardy-Weinberg berdasarkan sebaran alel lokus D7S1789 pada populasi monyet ekor panjang di Gunung Pusuk Lombok Barat.

\begin{tabular}{llll}
\hline Genotipe & Observasi & Harapan & $\mathrm{X}^{2}$ \\
\hline $121 / 121$ & 10 & 10,721 & 0,048 \\
$121 / 130$ & 7 & 5,559 & 0,374 \\
\hline Total & 17 & 16,279 & 0,422 \\
\hline
\end{tabular}

Perhitungan hasil uji kawin acak berdasarkan keseimbangan HardyWeinberg (Tabel 2). Berdasarkan sebaran alel menggunakan uji Chi-square didapatkan hasil $\chi_{\text {hitung }}^{2}=0,422\left(\chi_{\text {tabel }}^{2}=\right.$ $3,841 ; \alpha=0,05 ; \mathrm{db}=1)$. Ini membuktikan 
bahwa populasi monyet ekor panjang di Gunung Pusuk masih kawin acak.

Masih terjadinya kawin acak pada populasi Gunung pusuk sangat berbanding terbalik dengan jumlah alel dan nilai heterozigositas yang rendah. Kuat dugaan bahwa rendahnya heterozigositas populasi monyet ekor panjang di Gunung Pusuk berkaitan dengan efek founder (Frankham et al., 2004) yang menjelaskan bagaimana populasi awalnya terdiri atas sedikit individu. Selain itu, pembangunan infrastruktur yang ada di sekitar lokasi Gunung pusuk seperti pemukiman memungkinkan populasi Gunung pusuk menjadi terisolasi dari populasi lainnya sehingga pejantan dewasa subdominan yang menjadi jembatan genetik dari populasi lain ke populasi Gunung Pusuk tidak dapat bermigrasi (Wandia, 2001). Ketiadaan migrasi dari populasi ini mengakibatkan aliran gen hanya terbatas dalam populasi tersebut tanpa adanya gen lain yang masuk.

\section{SIMPULAN}

Kesimpulan yang didapatkan dari penelitian menggunakan lokus D7S1789 di gunung Pusuk Lombok barat adalah jumlah alel dua dan bersifat polimorfik dengan heterozigositas yang rendah namun masih menunjukan tanda kawin acak.

\section{SARAN}

Peneliti menyarankan perlunya dilakukan penelitian serupa pada populasi lainnya dengan menggunakan marka molekul yang sama untuk mengungkap lebih banyak variasi genetik pada populasi lain

\section{UCAPAN TERIMAKASIH}

Peneliti mengucapkan terima kasih kepada kepala Laboratorium Pusat Penelitian Satwa Primata LPPM Universitas Udayana yang telah memfasilitasi penelitian ini, serta semua pihak lainnya yang telibat.

\section{DAFTAR PUSTAKA}

Alders M, Bikker H, Christiaans I. 2017. Homo sapiens a-kinase anchoring protein 9 (AKAP9), RefSeqGene (LRG_331) on chromosome 7. access point: $N G \_011623$. National Center for Biotechnology Information, US National Library of Medicine, Rockville Pike, Bethesda. https://www.ncbi.nlm.nih.gov/nuccore/ NG_011623.1?report=gbwithparts\&lo $\mathrm{g} \$=$ seqview (diakses tanggal 20 Maret 2017).

Allendorf FW, Luikart G, Aitken SN. 2013. Conservation and the genetics of populations. $2^{\text {nd }}$ Ed. United Kingdom, Willey and Blackwell.

Arisuryanti T, Daryono BS. 2007. Genetika populasi. Yogyakarta, Fakultas Biologi Universitas Gadjah Mada.

Balloux F, Lugon-Moulin N. 2002. The estimation of population differentation with microsatellite markers. Mol. Ecol. 11: 155-165.

De Ruiter JR, Geffen E. 1998. Relatedness of matrillines, dispersing and social groups in long tail macaques (Macaca fascicularis). Proc. R. Soc. Lond. 265:79-87.

Dewi EK, Soma IG, Wandia IN. 2013. Diversitas genetik populasi monyet ekor panjang menggunakan marka molekul mikrosatelit D3S1768. Indon. Med. Vet. 2(1): 43-57.

Dwiwandana B, Suatha IK, Wandia IN. 2013. Karakteristik lokus mikrosatelit D7S1789 pada populasi monyet ekor panjang (Macaca fascicularis) di Wanara Wana, Padang Tegal, Ubud, Bali. Indon. Med. Vet. 2(4): 375-384.

Eudey AA. 1994. Temple and pet primates in Thailand. Rev. Ecol. 49: 273-280.

Fooden J. 2006. Comparative review of fascicularis-group species of macaques (Primates: Macaca). Fieldiana Zool. 107: 1-43.

Frankham R, Ballou JD, Briscoe DA. 2004. A primer of conservation genetics. 
Cambridge, Cambridge University Press.

Gemayel R, Vinces MD, Legendre M, Verstrepen KJ. 2010. Variable tandem repeats accelerate evolution of coding regulatory sequences. Ann. Rev. Gen. 44: 445-477.

Hillis DM, Moritz C, Mable BK. 1996. Molecular systematics. $2^{\text {nd }}$ Ed. Sunderland MA: Sinauer Associates, Inc.

Karimullah, Anuar S. 2011. Social organization and mating system of Macaca fascicularis (long tailed macaques). Int. J. Biol. 3(2): 23-31.

Krawscjack M. Schmidtke J. 1994. DNA fingerprint. Oxford, BIOS Scientific Publisher Ltd.

Lang KC, Crockett C. 2006. Long tailed macacaque-Macaca fascicularis. Primate Info Net Library and Information cervice National Primate Research Center, University of Wisconsin - Madison. http://pin.primate.wisc.edu/factsheets/e ntry/long-tailed_macaque (diakses tanggal 10 Februari 2017).
Maharani D, Soma IG, Wandia IN. 2014. Karakteristik lokus mikrosatelit D10S1432 pada populasi monyet ekor panjang di Taman Nasional Alas Purwo Banyuwangi. Indon. Med. Vet. 3(3): 244-251.

Monica WS, Widyastuti SK, Wandia IN. 2012. Keragaman populasi monyet ekor panjang di Pura Pulaki menggunakan marka molekul mikrosatelit D13S765. Indon. Med. Vet. 1(1): 37-54.

Nei M. 1987. Molecular evolutionary genetics. New York, Colombia University Press.

Suartha IN, Putra IGAA, Wandia IN. 2002. Pembiusan monyet ekor panjang (Macaca fascicularis) jantan dengan campuran Ketamin dan Xylazin pada topografi daerah berbeda. J. Vet. 4(1): $15-20$.

Wandia IN. 2001. Variasi genetik monyet ekor panjang (Macaca fascicularis) di beberapa lokasi di Bali. Thesis. Institut Pertanian Bogor, Indonesia.

Wienberg J, Stanyon R. 1998. Comparative chromosome painting of primate genomes. ILAR J. 39(2-3): 77-79. 